\title{
Opposition to Recent Proposals Which Would Reject the Family Name Enterobacteriaceae and Escherichia As Its Type Genus
}

\author{
J. J. FARMER III, ${ }^{1}$ DON J. BRENNER, ${ }^{1}$ AND WILLIAM H. EWING ${ }^{2}$ \\ Enteric Section, Center for Disease Control, Atlanta, Georgia 30333, ${ }^{1}$ and 2364 Wineleas Road, Decatur, \\ Georgia $30333^{2}$
}

The name Enterobacteriaceae was proposed in 1937 by Rahn to include many taxa which are now included in the family. Rahn's proposal had several nomenclatural flaws, so with the retroactive application of the rules of 1948 International Bacteriological Code of Nomenelature, both Enterobacteriaceae Rahn 1937 and Enterobacter Rahn 1937 became illegitimate. However, since the name Enterobacteriaceae had become so widely used since 1937, the Judicial Commission voted to conserve it in 1958. Both the 1958 and 1975 Bacteriological Codes contained many statements that made Enterobacteriaceae a legitimate, conserved name and the only correct name for the family. After almost 20 years of universal acceptance, the name was challenged because it was the only family name not formed by adding "aceae" to the stem of the name of the type genus as required by Rule 21a of the 1975 Bacteriological Code. On 3 September 1978, the Judicial Commission voted to conserve the name Enterobacteraceae over Enterobacteriaceae even though the former name had never been published, had no description, was illegitimate, and had no standing in nomenclature. The arguments given to reject Enterobacteriaceae and its type genus Escherichia are not supported by the principles and rules of the Bacteriological Code. The proposal has not received the support of those who work with the family. In 1975 the International Committee on Systematic Bacteriology's Subcommittee on the Taxonomy of Enterobacteriaceae voted 12 to 2 against any change, and in May 1980, the American Society for Microbiology's Subcommittee on Gram-Negative Facultatively Anaerobic Rods voted 7 to 0 against any change. To maintain stability in nomenclature and prevent confusion in the literature, the conserved family name Enterobacteriaceae with its designated and conserved type genus Escherichia should be maintained.

The July 1979 issue of the International Journal of Systematic Bacteriology (IJSB) contains two proposals which need much discussion. The first occurs in the Minutes of the Meeting (18) of the Judicial Commission:

Minute 29. Rejection of the family name Entero bacteriaceae. The Commission discussed the case of the status of the family name Enterobacteriaceae in the light of the advice requested from the Subcommittee on Enterobacteriaceae (Minute 29, Int. J. Syst. Bacteriol. 24:379-380, 1974). The Commission decided that it would not permit exceptions to the rules (see Minute 9) and therefore decided, by 11 votes to 1 , to reverse Opinion 15 , which conserved the family name Enterobacteriaceae with the type genus Escherichia (Int. Bull. Bacteriol. Nomen. Taxon. 8:73-74, 1958). Instead, it proposed to conserve the family name $E$ nterobacteraceae with the type genus Enterobacter on the grounds that this would cause less disturbance than the change to the family name Escherichiaceae with the type genus Escherichia.
The second is the Request for an Opinion by S. P. Lapage to replace the family name Enterobacteriaceae with Enterobacteraceae and change its type genus from Escherichia to Enterobacter (21). In a much shorter paper in the ASM News (12), we brought this controversy to the attention of microbiologists, since almost no one was even aware that there was a controversy. In the present article we discuss this controversy from a nomenclatural standpoint.

Bacteriological nomenclature is currently governed by the 1975 Bacteriological Code (22), with six amendments approved by the International Committee on Systematic Bacteriology (ICSB) $(7,17)$. There is some confusion about whether the correct name is the "Bacteriological Code, 1976 Revision" or the "Bacteriological Code, 1975 Revision." The following statement appears on page 11 of the Code (under Rule 1): "It shall be cited as Bacteriological Code (1975 Revision)...." This 1975 date agrees with the 
1975 copyright date given on pages iii and iv. However, the words "Bacteriological Code 1976" appear on the side cover of the book and the words "Bacteriological Code 1976 Revision" appear under the title on page iii. If the Bacteriological Code is to govern stability in nomenclature, the Code itself must have a stable name, and we request the Judicial Commission to look into this matter and make appropriate revisions in the Code, thus correcting this source of confusion. Although the name "Bacteriological Code, 1976 Revision" seems to appear more frequently and has been used by the Judicial Commission (7), we see no choice but to follow Rule 1 and to use "Bacteriological Code, 1975 Revision" as specifically required by the wording of this rule. Henceforth we will refer to Bacteriological Code, 1975 Revision or simply to the 1975 Code (22). Before the precise wording of Rule $1(22$, p. 11) was noted, we used the term "1976 Bacteriological Code" (12). Other material besides the current Bacteriological Code is also pertinent to the discussion. This includes the first Code, called the International Bacteriological Code of Nomenclature, issued in 1948 (6; henceforth called the 1948 Code); the second Code, called the International Code of Nomenclature of Bacteria and Viruses, issued in 1958 (15; henceforth called the 1958 Code); and deliberations of previous Judicial Commissions and nomenclatural arguments from the pages of the International Bulletin of Bacteriological Nomenclature and Taxonomy and the IJSB.

To understand the present controversy, one must understand its historical development. A brief chronology of the names Enterobacteriaceae, Enterobacteraceae, Escherichia, and Enterobacter and of the Bacteriological Code follows.

Before 1930, it is unclear what, if any, rules "legally" governed the naming of bacteria.

In 1930, the first International Microbiological Congress meeting in Paris voted to follow the rules of nomenclatures agreed upon by International Congresses of Botany and Zoology "insofar as they may be applicable and appropriate." (From 1930 to 1948, it is unclear precisely what set of rules applied to bacteriological nomenclature.)

Before 1937, the genera now classified in the family Enterobacteriaceae had many different confusing classifications but were often placed in the family Bacteriaceae.

In 1937, Rahn proposed the name Enterobacteriaceae with one genus, Enterobacter, which was made up of many species now contained in the family. Thus in 1937, Enterobacteriaceae Rahn 1937 was based on the type genus Enterobacter Rahn 1937, since it was the only genus in the family. (Since there was no Bacteriological Code at the time, we do not see how definite statements can be made on the legitimacy or correctness of these names until the 1948 Code was issued.)

In 1939, the name Enterobacteriaceae Rahn 1937 appeared in the fifth edition of Bergey's Manual of Determinative Bacteriology (1, p. 388 ) and contained eight of the genera now in the family. It did not have a type genus listed and did not include the genus Enterobacter Rahn 1937.

In 1948, the first approved Bacteriological Code was published (6). Since its rules were applied retroactively to all bacterial names, the name Enterobacter Rahn 1937 became illegitimate (9), and the name Enterobacteriaceae Rahn 1937 also became illegitimate (9).

In 1948, the name Enterobacteriaceae Rahn 1937 was used in the sixth edition of Bergey's Manual, again with no type genus and without Enterobacter Rahn 1937.

In 1953, the International Committee on Bacteriological Nomenclature placed the family name Bacteriaceae on the list of rejected names $(15,16)$. Proposals were made to conserve the name Enterobacteriaceae Rahn 1937 and to replace the rejected name Bacteriaceae.

In 1957 , a formal proposal was made (10) for the Judicial Commission to: (i) conserve the family name Enterobacteriaceae, (ii) fix the type genus as Escherichia, and (iii) fix the type species of Escherichia as $E$. coli.

In 1958 (January), the Judicial Commission issued Opinion 15, which conserved the family name Enterobacteriaceae and the genus name Escherichia. It fixed the type genus for Enterobacteriaceae as Escherichia, with its type species as $E$. coli. The name of the family became Enterobacteriaceae Rahn 1937, nom. fam. cons. (Opin. 15, Jud. Comm. 1958) (henceforth referred to as Enterobacteriaceae Rahn 1937, nom. fam. cons. 1958). Enterobacteriaceae Rahn 1937 is a taxon different from Enterobacteria ceae Rahn 1937, nom. fam. cons. 1958, since the two family names are based on different type genera.

In 1958 (July-August) Opinion 15 was discussed by the International Committee on Bacteriological Nomenclature at its meeting at the Seventh International Congress for Microbiology at Stockholm. It became final since it was not revoked or modified $(15$, p. 125$)$.

From 1958 to the present, the name Enterobacteriaceae Rahn 1937, nom. fam. cons. 1958, gained worldwide acceptance.

In 1958, a revised Bacteriological Code was approved. Specific rules were put into the Code to make Enterobacteriaceae Rahn 1937, nom. 
fam. cons. 1958, a legitimate name, a conserved name, and the only correct name for the family.

In 1973, the Judicial Commission noted that the family name Enterobacteriaceae had not been formed according to Rule 3 of the 1958 Bacteriological Code but that it was a conserved name (20). The matter was to be referred to the ICSB Subcommittee on the Taxonomy of $E n$ terobacteriaceae (henceforth referred to as the Enterobacteriaceae Subcommittee) for a recommendation.

In 1975 , by a vote of 12 to 2 the Enterobacteriaceae Subcommittee reaffirmed Opinion 15 and recommended retaining the family name Enterobacteriaceae Rahn 1937, nom. fam. cons. 1958, with the type genus Escherichia.

From 1975 to 1976 , a revised version of the Bacteriological Code (22) was approved. Opinion 15 was reaffirmed.

On 3 September 1978, the Judicial Commission voted to conserve "... the family name Enterobacteraceae with its type genus Enterobacter..." (18).

In July 1979, the Judicial Commission published (18) Minute 9, "no exception to the rule on naming taxa," and Minute 29, "rejection of the name Enterobacteriaceae."

In July 1979, Lapage proposed Enterobacteraceae Lapage 1979 and requested an opinion of the Judicial Commission which would have replaced the name Enterobacteriaceae with Enterobacteraceae and the type genus Escherichia with Enterobacter (21).

In 1979, letters were sent to the Chairman of the Judicial Commission objecting to the proposal of Lapage (21) and to the vote of 3 September 1978 published in Minute 29 (18), which did not follow correct Judicial Commission procedure.

In 1980, the Approved Lists of Bacterial Names were published. Neither Enterobacteriaceae nor Enterobacteraceae appeared on the list. On 1 January 1980, Enterobacteriaceae Rahn 1937, nom. fam. cons. 1958, and Enterobacteraceae Lapage 1979 both lost standing in nomenclature. From 1 January 1980 until this time there has been no validly published name for the family previously known as Enterobacteriaceae.

In 1980, the American Society of Microbiology Subcommittee on Gram-Negative Facultatively Anaerobic Rods voted 7 to 0 against changing the name from Enterobacteriaceae to Enterobacteraceae and against changing the type genus from Escherichia to Enterobacter (12). (In all fairness it should be mentioned that two members of this Subcommittee [W.H.E. and D.J.B.] are authors of this paper).
In 1980, Enterobacteriaceae fam. nov., nom. rev. (a revived name) was proposed in a companion paper in this issue (11) as a revived name to fill the void which has existed since 1 January 1980.

Analysis of the arguments to reject Enterobacteriaceae. Seven arguments have been given for rejecting the family name Enterobacteriaceae and replacing Escherichia with Enterobacter as the type genus. Lapage gives four of them: three in his article in IJSB (21) and one in a letter. Two other arguments used by the Judicial Commission in arriving at their decision to reject Enterobacteriaceae (18) have been relayed to us by the current chairman of the Judicial Commission (Lawrence G. Wayne, personal communication). The seventh argument is given in Minutes 9 and 29 issued by the Judicial Commission (18). Each one of these arguments needs to be discussed in relation to the Bacteriological Code.

Argument 1 by Lapage. It is stated (21) that Enterobacteriaceae Rahn 1937 is an illegitimate but conserved name. We agree that $E n$. terobacteriaceae Rahn 1937, used from 1937 to 1958 , is an illegitimate name (9). It became illegitimate with the retroactive application of the 1948 Code. However, in 1958 the name was conserved by Opinion 15 of the Judicial Commission and became Enterobacteriaceae Rahn 1937, nom. fam. cons., Opin. 15, Jud. Comm. 1958. Thus, from 1958 to the present this latter name has been the correct one for the family, not Enterobacteriaceae Rahn 1937 as stated by Lapage. This is an important nomenclatural point since Enterobacteriaceae Rahn 1937 was based on Enterobacter Rahn 1937, and both names became illegitimate in 1948. Enterobacteriaceae Rahn 1937, nom. fam. cons. 1958, is based on Escherichia Castellani and Chalmers 1919 nom. gen. cons., designated type genus, Opin. 15, Jud. Comm. 1958 (henceforth referred to as Escherichia Castellani and Chalmers 1919, nom. gen. cons. 1958) and has been in conformity with both the 1958 and the 1975 Bacteriological Codes. Enterobacteriaceae Rahn 1937 is illegitimate, but Enterobacteriaceae Rahn 1937, nom. fam. cons. 1958, is legitimate, and they are different taxa because they are based on different type genera. The late R. E. Buchanan (a former chairman of the Judicial Commission), J. G. Holt (an ex-officio member of the current Judicial Commission), and E. F. Lessel (an ex-officio member of the current Judicial Commission) agree that Enterobacteriaceae Rahn 1937, nom. fam. cons. 1958, was validly published and legitimate. This is clearly stated on p. 550 of Index Bergeyana (5). It became legitimate when Opin- 
ion 15 was issued and when the 1958 Bacteriological Code (15) was modified to accommodate this exception.

Argument 2 by Lapage. Lapage argues (21) that the change will result in only "minimal disturbance" of nomenclature.

This course has the merit of producing a minimal disturbance of existing nomenclature, because for practical purposes the only change is a small difference in spelling, i.e., the omission of the letter " $i$ " from the presently used family name. Such a change is unlikely to cause much difficulty for future bacterial systematists, because it should be no more disturbing than changes produced by emendation of the spelling of names that have been inadvertently spelled incorrectly (e.g., emendation of Hemophilus to Haemophilus). The change does not affect the first part of the word, and therefore it should seldom disturb the position of the family name in alphabetized lists."

The change in spelling itself may or may not cause problems for specialists in bacterial nomenclature, but it would be a constant source of confusion for general microbiologists, students, physicians, medical technologists, journal editors, abstract services, indexers, and every nonexpert who deals with the word. It would be especially annoying in computer science, since the two words are different, although they differ by only one letter. For example, a computer abstract search in Index Medicus for Entero. bacteriaceae would not pick up citations for Enterobacteraceae and vice versa. Enterobacteraceae would not appear as a subject heading, but Enterobacteriaceae would. Every computer program in existence today would have to be modified, and a cross-reference would have to be added for this variant spelling. Computer programmers will certainly oppose this proposed change. In our laboratory alone, we have over 100 computer programs which deal with Enterobacteriaceae. The changes in the programs and their existing documentation would require many hours of valuable programming time. On a worldwide basis, this loss of programming time would be enormous.

We estimate that the word Enterobacteria. ceae has appeared in the literature over 100,000 times since it was introduced in 1937. If the word Enterobacteraceae were to be used instead, it would take many years for it to appear 100,000 times. The literature would be confused for many years by these two words with such similar spellings. This is in contrast to the example Lapage cites because of the limited use of $\mathrm{He}$. mophilus compared with Enterobacteriaceae. It should also be pointed out that the amended spelling Haemophilus was and is a source of confusion. Several microbiologists or editors have tried to correct the spelling of Hemophilus in our sentences (12) about Hemophilus being in the family Bacteriaceae in the fifth edition of Bergey's Manual. On page 276 of our ASM News article (12), the word "Haemophilus" was inserted incorrectly for "Hemophilus" by a copy editor (we did not receive a galley proof to correct). In the fifth edition of Bergey's Manual, Hemophilus did appear, not Haemophilus. Concerning the change in spelling of Hemophilus to Haemophilus, even the late R. E. Buchanan, who required very strict application of the rules (22, p. xii), advocated retaining original spellings (3, p. 27): "However, in general, it is well to observe the rule that the original spelling of the word be conserved, unless it can be regarded definitely as a slip of the pen."

Wayne cites three excellent examples of the confusion that can be caused when two bacterial names differ in spelling by only a single letter (30). The names in question were two species of Mycobacterium, $M$. marianum and $M$. marinum. Wayne states:

(i) (Lawrence G. Wayne) In two instances, galley proofs were received in which $M$. marinum was set where $M$. marianum had actually appeared in the original manuscript. In one of these papers (10), the error was detected in proof and cited in a letter dated May 26, 1969, to Lucile Myers, secretary to R. E. Buchanan, who was then editor of this journal. In the other paper (9), the error escaped attention in proof and appeared in the caption to Fig. 4. This error was pointed out in subsequent correspondence (7).

(ii) (Lawrence G. Wayne) In a letter dated February 26,1969 , over the signature of R. E. Buchanan, then editor of this journal, the following statement appears: "The manuscript, 'On the Synonomy of Mycobacterium marinum (sic) Penso 1953 and Mycobacterium scrofulaceum Prissick and Masson 1956, and the Resolution of a Nomenclatural Problem' by Wayne and Lessel has been accepted for publication...." Even so scrupulous a nomenclaturist as Prof. Buchanan failed to note that the second " $a$ " had been dropped from "marianum" in his letter.

(iii) (Ernest H. Runyon) For nine years, 1956-1965, a strain in the National Collection of Type Cultures, London, was listed as $M$. marinum when actually it was (and is) $M$. marianum.

Wayne was so concerned about the confusion in the literature that had resulted and could result that he asked the Judicial Commission to go against the rules of nomenclature and conserve scrofulaceum over marianum (30). He made this argument even though marianum was the oldest and therefore the correct name for the organism under the Bacteriological Code. The Judicial Commission agreed and made an exception to the rules because it was in keeping 
with the purpose of the rules, which is to prevent confusion.

In the above-mentioned situation with marinum and marianum, the names refer to different taxa. Some have argued that Enterobacteriaceae with Escherichia as the type genus is the same taxon as Enterobacteraceae with Enterobacter as the type genus. This is not so, because a taxon is operationally defined only in terms of its type. Making Enterobacter the type genus changes the definition and concept of the family considerably, even though its basic description (21) is very similar to the description given for Enterobacteriaceae with Escherichia as the type genus. If Enterobacteriaceae and Enterobacteraceae did refer to the same taxon, as argued by Lapage, it would cause instability in nomenclature to change the type genus from one which was definitively fixed over 20 years ago (20).

Argument 3 by Lapage. This argument is that Enterobacter can easily be substituted for Escherichia as the type genus for the family (21).

This course seems to lead to less disturbance than the alternative of retaining the present type genus and changing the family name to Escherichiaceae. The genus Enterobacter appears to be quite typical of the family, and it is very adequately known and defined. It has a well-defined type species, Enterobacter cloacae (Jordon 1890) Hormaeche and Edwards 1960, with an accepted neotype strain, CDC 276-56 (= NCTC $10005=$ ATCC 13047), proposed by Hormaeche and Edwards (3). The name Enterobacter has been conserved (6).

Scientific data do not support the argument that Enterobacter would be a good type genus. Many lines of evidence, including genetic mapping, deoxyribonucleic acid (DNA)-DNA hybridization, and amino acid sequencing of specific proteins, indicate that the "core genera" of the family Enterobacteriaceae are Escherichia-Shigella-Salmonella-Citrobacter. The genera of the tribe Klebsielleae, which includes Enterobacter (4), have diverged somewhat from this core group. Thus the best representative of the family as most people have understood and defined it is Escherichia, not Enterobacter. It is essential that the type genus include $E$. coli, the living organism best understood at the molecular level. In deciding whether a new genus belongs in Enterobacteriaceae, it should be compared with the type genus of the family. Very little is known about Enterobacter at the molecular level in contrast to Escherichia. Many comparisons, such as nucleotide sequencing, genetic mapping, and structure of specific proteins, etc., cannot be done with Enterobacter but can be done with Escherichia. Those who doubt that the family Enterobacteriaceae is defined in terms of its type genus Escherichia, which is in turn defined in terms of its type species, $E$. coli, should consult the three papers on Enterobacteriaceae in volume 16 of $A d$ vances in Genetics $(2,24,26)$. In these papers, intrafamily and interfamily comparisons were made in terms of Escherichia and its type species, E. coli.

A specific example to answer the question "Does Salmonella typhimurium belong in the family Enterobacteriaceae?" can be found in the work of Middleton (23), who used bacteriophage P22-mediated transduction of hybrids which result from conjugation matings between E. coli and Salmonella typhimurium. With this approach he was able to compare the genetic homology of these two species at many loci around the genetic map. He commented on the usefulness of this and similar genetic techniques in comparing the evolutionary divergence of different taxa. In making interfamily and intrafamily comparisons, it would be a marked disadvantage to have Enterobacter as the type genus rather than Escherichia. Very little is known about Enterobacter compared with the "core" genera of the family Enterobacteriaceae.

Enterobacter is a conserved name, but it is also an illegitimate name (9), a point not mentioned by those who have favored this change. In 1948 Enterobacter Rahn 1937 became illegitimate. In 1960 Hormaeche and Edwards proposed Enterobacter (not Enterobacter Rahn 1937) based on the type species Enterobacter cloacae; however Enterobacter Hormaeche and Edwards 1960 was also illegitimate since it was a junior synonym to Cloaca cloacae Castellani and Chalmers 1919, which was validly published and legitimate (5). Cloaca cloacae was not illegitimate under Rule 25c (tautonymy) of the 1958 Code because it was not an exact repetition of the generic name in the species name. This latter name, Enterobacter, only became legitimate in 1963 when it was conserved by Opinion 28 . Thus, Enterobacter has twice been illegitimate, first as Enterobacter Rahn 1937 and then as Enterobacter Hormaeche and Edwards 1960. It only became legitimate as Enterobacter Hormaeche and Edwards 1960, nom. gen. cons. (Jud. Comm. Opin. 28, 1963) (henceforth written as Enterobacter Hormaeche and Edwards 1960, nom. gen. cons. 1963). We believe it would be illogical and confusing to replace the legitimate and conserved name Enterobacteriaceae with Enterobacteraceae based on Enterobacter, which has been illegitimate more often and longer than it has been legitimate.

Another possible nomenclatural problem with Enterobacter as the type genus concerns the union of Enterobacter with Erwinia, which was 
mentioned in 1978 by Thurner and Busse (29). Others have also commented on the similarity of these two genera. Rule 42 of the 1975 Code $(22$, p. 38$)$ indicates which of the two generic names would be retained for the redefined genus: "In the case of subspecies, species, subgenera and genera, if two or more of the taxa are united, the oldest legitimate name or epithet is retained...."

If these two genera are united, the resulting genus becomes Erwinia since Erwinia Winslow, Broadhurst, Buchanan, Krumwiede, Rogers, and Smith 1920 predates Enterobacter Hormaeche and Edwards 1960, nom. gen. cons. 1963, by over 40 years.

The designation of Enterobacter Hormaeche and Edwards 1960, nom. gen. cons. 1963, as the type genus would cause confusion in still another way. Klebsiella and Enterobacter (and often Serratia) have traditionally been placed in the tribe Klebsielleae, as was done in the eighth edition of Bergey's Manual (4). If Enterobacter is made the type genus for the family Enterobacteriaceae, then Rule $1 \mathrm{~A}$ requires coining of the tribal name Enterobactereae to include the type genus. Much confusion would result over the definition and use of Klebsielleae and Enterobactereae. This is another confusing situation which can be avoided by retaining the status quo, since the tribal name Escherichieae, based on the type genus Escherichia, appears on the 1980 Approved Lists. Thus, Enterobacter Hormaeche and Edwards 1960, nom. gen. cons. 1963, is totally unsuitable as the type genus for Enterobacteriaceae.

Argument 4 by Lapage. This argument was contained in a letter from P.H.A. Sneath, Chairman of the Judicial Commission (at that time) to Leon Le Minor, Chairman of the Enterobacteriaceae Subcommittee (at that time). In the letter the statement is made:

The Judicial Commission wished to remove the anomaly of the family name Enterobacteriaceae Rahn 1937 (p. 280) which does not conform to Rule 21a. This family name was conserved by an opinion of the Judicial Commission (Opinion 15 (1958) IJSB 8, 7374) with Escherichia Castellani and Chalmers 1919 (p. 941 ) as the type genus. The opinion also specifically states that it can be revoked by the action of the ICSB at a future date.

It appears that the last sentence in the quoted passage is being used as the judicial basis for the proposal (18) "to overturn Opinion 15." This cannot be used as the basis, because the actual opinion (19) says something quite different from the words in the letter: "The result of the vote authorizes the Editorial Board acting for the Judicial Commission to publish the following OPINION. This OPINION is final unless re- voked or modified by action of the International Committee on Bacteriological Nomenclature."

Opinion 15 was issued under the 1958 Code, which states $(15$, p. 125$)$ :

Functions of the International Committee. The International Committee on Bacteriological Nomenclature has the following functions:...

(3) To consider all Opinions issued by the Judicial Commission. Such opinions become final unless rejected by majority vote at the meeting of the Committee next following the date on which the opinion was published or submitted to the Committee.

Thus, the wording of Opinion 15 and other similar opinions was in relation to this statement on p. 125 of the 1958 Code. Opinion 15 became final in 1958 when it was not modified or rescinded by the International Committee on Bacteriological Nomenclature which met in Stockholm. The wording of the Bacteriological Code is clear on this point; the International Committee on Bacteriological Nomenclature did not leave this issue open forever. The opinion became final in August of 1958.

Argument 5 discussed by the Judicial Commission. This argument is that since 1980 is the time of drastic nomenclatural change, it is also the time to remove this "anomaly." Since neither Enterobacteriaceae nor Enterobacteraceae appeared on the 1980 Approved Lists of Bacterial Names (27), the (proposed) advantage of making the change is now gone.

Argument 6 discussed by the Judicial Commission. This argument has to do with the possibility of nomenclatural problems arising if Enterobacteriaceae is allowed to remain. Any such problem can easily be avoided with little foresight. If it ever becomes desirable to move Enterobacter to a new family (we cannot even conceive of this possibility), confusion is easily averted. For example, if Enterobacter, Klebsiella, and Erwinia were to be moved to a new family (which, on the basis of scientific data, is an infinitesimally small probability), then the new family name should not be derived from Enterobacter because Enterobacteraceae would be confused with the conserved name Enterobacteriaceae Rahn 1937, nom. fam. cons. 1958. Instead, the new family could be named Klebsiellaceae or Erwiniaceae.

Future nomenclatural problems can be avoided if Enterobacteriaceae Rahn 1937, nom. fam. cons. 1958, with its type genus Escherichia, is maintained. As previously mentioned, future problems and current confusion in the literature are more likely for Enterobacteraceae with its type genus Enterobacter.

Argument 7 by the Judicial Commission. This argument (19) causes us the greatest concern because it indicates that a "policy" of a 
Judicial Commission takes precedence over principles and rules of the Bacteriological Code and can be used to overturn an opinion issued by a previous Judicial Commission which has been finalized by the International Committee on Systematic Bacteriology.

In 1979 the Judicial Commission issued the following minute: "Minute 9. Policy on exceptions to Rules. The Commission reaffirmed its policy of not permitting exceptions to the Rules on the formation of names of taxa."

The whole controversy over the name Enterobacteriaceae concerns the fact that its formation goes against this minute. The minute cited above has no standing under the Bacteriological Code, yet it is given as the basis for all the exceptions in the Code that the rejection of Enterobacteriaceae and acceptance of Enterobacteraceae would require. It took many years of due judicial process to make Enterobacteriaceae a legitimate and correct name. This cannot be negated simply by issuing Minute 9 ; the Code itself would have to be modified. To do otherwise would be a serious procedural error.

Family names are now formed according to Rule 9 (22, p. 13) of the 1975 Code. However, in 1937 when Rahn was forming a name for his proposed new family, there was no approved Bacteriological Code of Nomenclature, even though the need for such a code has been clear to early microbiologists. Discussion and early drafts appeared in the 1930's and 1940's. However, it was not until the Bacteriological Code appeared in the March 1948 issue of the Journal of Bacteriology (6) that an approved version became generally available to microbiologists. Before the approved Bacteriological Code became available, microbiologists had no official guide. In the second published version of the Bacteriological Code, this period was summarized as follows $(15, \mathrm{p}$. v): "Many bacteriologists followed the Botanical Code, some the Zoological Code, and others named the organisms which they discovered with scant attention to established rules."

Thus, in 1937 when Rahn coined the name Enterobacteriaceae, it was in harmony with established practice and did not violate the Bacteriological Code, since none existed. The derivation of the family name Enterobacteriaceae Rahn 1937 was even in harmony with the first approved version of the Bacteriological Code (6, p. 290) when it appeared 11 years later: "Rule 1. Names of divisions, subdivisions, classes, subclasses, orders, suborders, families, subfamilies, tribes and subtribes are taken from their chief character or from a taxonomic unit of the next lower rank."

Rahn did not clearly state the derivation of
Enterobacteriaceae in his original paper (25), but it appears to come from adding "aceae" to the root of enterobacteria (enterobacteria, living in the intestine; Greek: enteron, intestine) as subsequently permitted by Rule 1 of the 1948 Code. This explanation (based on the chief characteristic) seems more likely than its formation from the genus Enterobacter Rahn 1937, since the family name in that case would have been Enterobacteraceae.

It was not until the 1958 Bacteriological Code that the derivation of the name Enterobacteriaceae conflicted with any rule. Rule $3(3$, p. 22$)$ states: "Names of taxonomic groups (taxa) between suborder and genus are formed by the addition of the appropriate suffix to the stem of the name of the type genus." However, the writers of the 1958 Bacteriological Code recognized that some names (particularly old ones) would not conform to their revision of the 1948 Code. They specifically discussed (8) and specifically added (8) a safeguard to minimize confusion and to allow continued use of names which were widely used but "not in accordance" with Rule 3. The first volume of the International Bulletin of Bacteriological Nomenclature and Taxonomy provides insight on why these exceptions were permitted (1). The following statement appears in an article specifically dealing with old family names $(8$, p. 62):

To avoid disadvantageous changes in certain old widely used families, such names, even though not conforming to Rule 3, may be recognized and accepted as exceptions (3) when approved by the International Committee on Bacteriological Nomenclature. ... Proposal for Exceptions. It is proposed that the following family names of bacteria be recognized as exceptions to Rule 3 on the basis that they are old names or are widely used. ... Enterobacteriaceae....

Provision 2 of the 1958 Bacteriological Code $(15$, p. 123$)$ contains a similar statement: "Lists of Nomina Conservanda-To avoid disadvantageous changes in the rules of nomenclature of the genera by the strict application of the Rules of Nomenclature, the Rules provide for a list of names which must be retained as exceptions (nomina conservanda)."

We believe that the words "must be retained as exceptions" (referring to conserved names) specifically argue against Lapage's proposal (21).

Safeguards to preserve old names with universal acceptances were clearly provided. The safeguards have continued to the present. The principles, rules, or opinions which allow for these exceptions have clearly been in line with Principle $1(22$, p. 7$)$, which states that one of the essential points in nomenclature is "to aim at fixity of names." It is significant that the 1948, 
1958, and 1976 Bacteriological Codes all state in the first principle that the purpose of nomenclature is to prevent names from changing, to avoid names which may cause error or confusion, and to avoid the useless creation of a name when a correct one already exists.

In 1953, at the International Congress for Microbiology in Rome, the International Committee on Bacteriological Nomenclature, upon recommendation of the Judicial Commission, placed the family name Bacteriaceae (the genera now in Enterobacteriaceae had previously been in this family) on the list of rejected names and proposals were made to replace the family name Bacteriaceae by conserving the family name Enterobacteriaceae and the genus name Escherichia. A proposal was then formally made to conserve the family name Enterobacteriaceae and to conserve the genus name Escherichia (with its type species being $E$. coli) and to make it the type genus of the family Enterobacteriaceae (10). The name Enterobacteriaceae was in accord with Rule 1 of the 1948 Bacteriological Code; however, it would have to be an approved exception to Rule 3 of the 1958 Code. It was permitted by Provision $2(15$, p. 123) if the Judicial Commission agreed and if its action was subsequently not "modified or rejected" by the International Committee on Bacteriological Nomenclature at its next meeting. Haupt (13) argued vigorously against the proposal to conserve Enterobacteriaceae because it would be an exception to the rules:

To ask microbiologists to agree to the conservation of a name which has been introduced and used in contravention to the internationally approved rules, might well undermine the fundamentals of the bacterial nomenclature. This would seem to constitute a precedent such that any name of a taxon may be validated, if only bacteriologists accept the name in a textbook. We are confronted by a rather serious situation; it is possible that such a proposal might open the way for common disregard of rules.

This argument might be paraphrased as "the rules of bacteriological nomenclature are more important than the purpose of having rules." In the formal request (10) to conserve the name Enterobacteriaceae with the type genus Escherichia, the Editorial Board of the Judicial Commission disagreed with Haupt's argument and based much of its argument on Principle 1: "there has been such widespread acceptance and use of the family name Enterobacteriaceae by authors; by the Enterobacteriaceae Subcommittee of the International Committee; by various bacteriological manuals, in abstracting journals; and in textbooks" that it should be conserved. At this stage the option was clearly open to reject the family name Enterobacteriaceae and form a new family Escherichiaceae from the type genus Escherichia, if Enterobacteriaceae were to be rejected. Strict application of Rule 3 would require this, but this confusing option was never even discussed because the name Enterobacteriaceae had been so widely used for 20 years. In 1957 the Judicial Commission issued Opinion 15, which conserved the name Enterobacteriaceae with Escherichia as the type genus (19).

Thus, it appeared that a final decision had been made. Although the name Enterobacteriaceae did not agree with Rule 3 of the 1958 Bacteriological Code, it would be conserved to provide stability in nomenclature. The following bodies endorsed this action: the American Society for Microbiology Subcommittee on Enterobacteriaceae, the International Subcommittee on the Taxonomy of Enterobacteriaceae, the Judicial Commission, the International Committee on Bacteriological Nomenclature, and apparently the scientific community. In 1958, the name Enterobacteriaceae was placed on the list of conserved family names, where it has remained for over 20 years. It was specifically listed as a conserved family name in the 1958 Code $(15$, p. 165) and the 1975 Code $(22$, p. 69$)$. Many citations in both these codes refer specifically to this exception. The wording of several of them is explicitly to make Enterobacteriaceae Rahn 1937, nom. fam. cons. 1958, the correct name of the family under the Bacteriological Code. After much discussion in the pages of the International Bulletin of Bacteriological Nomenclature and Taxonomy over the period of 5 years and after due judicial process, the issue appeared to be settled. After almost 20 years of universal acceptance of Enterobacteriaceae Rahn 1937, nom. gen. cons. 1958, the name was challenged $(7,9)$. This challenge came not because the name was causing confusion or instability in nomenclature but because it was the only exception to a rule.

The Bacteriological Code has been carefully developed over almost 50 years to provide a set of rules that are independent of the human personality. The Judicial Commission is granted certain power to decide matters in carefully defined instances; however, the rejection of the name Enterobacteriaceae Rahn 1937, nom. fam. cons. 1958, totally contradicts the judicial process that has brought us out of nomenclatural chaos. We strongly oppose the notion that the Bacteriological Code is what a particular Judicial Commission says it is. If this were true, bacteriological nomenclature could be governed by a group of appointed or elected individuals without the need for a Bacteriological Code. 
The remainder of this paper concerns the specific principles, rule, or opinions which argue against the rejection of Enterobacteriaceae.

Proposed nomenclatural changes and their relationship to the principles given in the Bacteriological Code. In the previous section, specific arguments were made against the proposed nomenclatural changes. In this section, general arguments will be made based on the principles given in the Bacteriological Code. Our argument can be summarized in one sentence: the proposed changes would contradict the purpose of having a Bacteriological Code because they would cause instability in nomenclature and much unnecessary confusion in the literature.

The chief reason for opposing these proposed changes is that they are so clearly contradicted by all three statements of the first principle of nomenclature $(22$, p. 7). "Principle 1 . The essential points in nomenclature are as follows. (1) Aim at stability of names. (2) Avoid or reject the use of names which may cause error or confusion. (3) Avoid the useless creation of names." This is such an elegant statement of our position that we are tempted to rest our entire argument on it. Even if the name Enterobacteriaceae had not been conserved over 20 years ago by Opinion 15 (19), we would argue that it must be conserved now because of Principle 1. Many authors have realized the importance of this principle, and many exceptions have been made to the rules because strict adherence would have violated it. Sneath based his argument to conserve the genus Chromobacterium (28) on Principle 1: "Conservation would be in accord with the principle of fixity of names, and a new name would cause confusion, since the generic name has been in general use since 1918." This was a period of 38 years. The parallel of Chromobacterium with the name in the present dispute, Enterobacteriaceae Rahn 1937, nom. fam. cons. 1958, is striking. For Enterobacteriaceae, the statement would read: "A new name would cause confusion, since the family name has been in general use for 43 years and has been on the conserved list of family names for 22 years." In requesting an opinion on another point in Chromobacterium, Sneath states $(28$, p. 68$)$ : " 8 . It would be more in accord with the principles of nomenclature to conserve ... since the former is closer to the concept of the genus as it is used today." This argument also has a parallel in the current dispute because most microbiologists' concept of the family Enterobacteriaceae centers around the type genus Escherichia. It is not based on less well-studied genera, such as Enterobacter, Citrobacter, or Edwardsiella. Enterobacteriaceae with Escherichia as the type genus is, to paraphrase Sneath, the concept of the family as it is accepted today. These statements illustrate the importance placed on Principle 1 in going against the rules to avoid a confusing situation. As discussed previously, Wayne (30) used a similar argument in requesting the conservation of scrofulaceum over marianum. Thus, two different Chairmen of the Judicial Commission have used Principle 1 as the reason for using names not in conformity with every rule in the Code. Principle 1 has been cited many times for going against a specific rule if the exception would give stability to nomenclature or prevent confusion. We contend that Principle 1 is the most important statement in the entire code, and all decisions must be based on its application to the specific circumstances. In his memorial to Robert E. Buchanan (22, p. xii), the late S. T. Cowan comments on the conflict which is sometimes apparent between Principle 1 and the many pages of rules, recommendations, lists, examples, and legal phrases which follow:

For the remaining years of his life preparations and plans for the eighth edition of Bergey's Manual occupied Buchanan's attention. He built up a team of strong-minded individualists who battled for several years with the problems leading to a new edition, and authors were chosen and invited to become contributors. Though he was interested primarily in the nomenclature, Buchanan never yielded a point and sometimes had authors and trustees tearing their hair at his insistence on a strict adherence to his beloved Code. With his attention focused on the names to be used in the Manual, his energies were dissipated on trivia; priority was always paramount, he was not concerned with usage or with the confusion that could arise when names were changed to conform with a strict application of the rules of nomenclature. ...

The implication is that the late Dr. Buchanan thought the rules of nomenclature were of paramount importance, but that the late Dr. Cowan felt the strict application of the rules was undesirable if it would lead to confusion. Let there be no doubt on our position; we favor minimizing confusion at the small cost of having a few exceptions to the rules. It makes no sense to follow blindly the rules which cause confusion or instability in nomenclature; this would contradict the purpose of having rules in the first place. In the case of Enterobacteriaceae, strict application of Rule 9 (formation of family names) would do nothing but cause unnecessary confusion.

The proposed action also violates both parts of Principle 8: "Each order or taxon of a lower rank with a given circumscription, position, and rank can bear only one correct name, i.e., the earliest that is in accordance with the Rules of 
this Code. Provision has been made for exceptions to this Principle (see Rules 23a and 23b and the Statutes of the ICSB)."

The name Enterobacteriaceae Rahn 1937 became illegitimate in 1948 with the approval of the 1948 Code. However, Enterobacteriaceae Rahn 1937, nom. fam. cons. 1958, became a correct, conserved, and legitimate name in 1958 (5), and it has been the only correct name of the family since that time $(15,22)$. The Bacteriological Code is quite clear on this point. Therefore, Enterobacteriaceae Rahn 1937, nom. fam. cons. 1958, is a senior synonym of Enterobacteraceae Lapage 1979 by over 20 years. To make Enterobacteraceae the correct name of the family, an exception would have to be made to Rules 23 a and $23 \mathrm{~b}$. This exception in itself would be contradictory to the Judicial Commission's position, since Minute 9 said there would be no exceptions in the formation of names.

The proposed action violates the intent of Principle 9: "The name of a taxon should not be changed without sufficient reason based either on future taxonomic study or on the necessity of giving up a nomenclature that is contrary to the rules of this code."

Since the original decision in 1958, taxonomic studies have indicated that Escherichia is part of the "core genera" in the evolution of Entero. bacteriaceae, and that Enterobacter has diverged from this core. Thus, taxonomic studies indicate the wisdom of the original decision and contradict the proposed one. Clearly, Enterobacteriaceae Rahn 1937, nom. fam. cons. 1958, is not contrary to the rules of the 1975 Code. This point is specifically covered in Rule $21 \mathrm{~b}$ and List 1 (22), and thus the current proposal would change a name without fulfilling either of the two reasons given by Principle 9 .

Proposed nomenclatural changes and their relationship to the rules and to judicial procedure given in the bacteriological code. The proposed action would violate the intent of Rule 1 b $(22$, p. 11): "Alterations to this Code can only be made by the ICSB at one of its plenary sessions. Proposals for modifications should be made to the Editorial Secretary in sufficient time to allow publication in the IJSB before the next International Congress of Bacteriology. For this and other Provisions, see the Statutes of the ICSB, pp. 131-150."

The proposed action would circumvent this important rule and let a "policy" given only in the minutes of a meeting (18) of the Judicial Commission rewrite many essential parts of the Code (Principles 1, 8, and 9, Rules 21b and 56b, Opinion 15, and List 1). We argue that the proposed changes cannot be made legally under the Bacteriological Code. The Code would have to be modified, and the procedure for doing this is given under Rule 1b. General Consideration 6 $(22$, p. 3) discusses the position of principle, rule, and recommendation. Since no mention is even made of a "policy," we see no possibility of a nomenclatural argument which would say that a policy takes precedence over principles, rules, or opinions.

The proposed action goes against the intent of Rule 4: (22, p. 11): "In the absence of a relevant Rule or where the consequences of a Rule are uncertain, a summary in which all pertinent facts are outlined should be submitted to the Judicial Commission for consideration (see Appendix 8 for preparation of a Request for an Opinion)."

Neither one of the two reasons to call on Rule 4 applies in this case. There is no absence of a relevant Rule; Rule $21 \mathrm{~b}$ is quite clear on the correctness of the name Enterobacteriaceae and its designated type genus, Escherichia. The consequences of maintaining Enterobacteriaceae were previously discussed in relation to avoiding future nomenclatural problems.

The proposed change violates the intent of Rule $21 \mathrm{~b}$, which was specifically written over 20 years ago for this situation: "If the name of a family was not made in conformity with Rule $21 \mathrm{a}$ but its name has been conserved, then the type genus may be fixed by an Opinion of the Judicial Commission. Example: The genus Escherichia is the type genus of the family Enterobacteriaceae (Opinion 15)."

The Judicial Commission presumes it has the power to change the type genus fixed by a previous Judicial Commission. The question arises as to whether this was the intent of any of the Bacteriological Codes. An interesting statement on the status of a name "fixed" by the Judicial Commission is in the 1958 Code $(15$, p. 54): "The nomenclatural type of none of the named subclasses, orders, and suborders in bacteriology has thus far not been definitely fixed either by designation or by action of the Judicial Commission."

This statement follows statements about the Judicial Commission fixing the type genus of a family name not in conformity with Rule 3 (15, p. 53). This wording in the 1958 Bacteriological Code clearly indicates that in 1958 the genus Escherichia was "definitely fixed" as the type genus for the family. At least the 1958 Judicial Commission and the writers of the 1958 Code intended that it was "definitely fixed." The word "definitely" would not have been used if this was subject to revocation in the future. Opinion 15 must stand unless a change in classification requires the opinion to be examined. This is specifically covered in Rule $56 \mathrm{~b}$. Thus far, no change 
in classification has occurred to cause this reexamination. Opinion 15 must stand until such a change occurs (such a change is very unlikely).

The proposed action violates the intent of Rule 23a and Note $4(22$, p. 23) under this rule:

Each taxon above species, up to and including order, with a given circumscription, position, and rank can bear only one correct name, that is, the earliest that is in accordance with the Rules of this Code....

Note 4. The Judicial Commission may make exception to Rule 23a by the addition of names to the list of conserved names (nomina conservanda) or to the list of rejected names (nomina rejicienda) (see Appendix 4). The Judicial Commission may correct the approved lists (see Rule 24a).

(i) By conserved name (nomen conservandum) is meant a name which must be used instead of all earlier synonyms and homonyms. By rejected name (nomen rejiciendum) is meant a name which must not be used to designate any taxon. Only the Judicial Commission can conserve or reject names (see also Rules 56a, b)....

This rule was written to give stability to nomenclature, and provisions were made in Note 4 to preserve names not in conformity with a rule. The use of exceptions was required to maintain stability of names as given in Principle 1. This argument was fully developed in the debate which led to Opinion 15 in 1958. The arguments for conserving family names not in accord with all rules were fully developed in a policy statement of the Judicial Commission specifically dealing with this subject (8). This matter was thoroughly analyzed and discussed from 1951 until 1958, when it was definitively settled.

The proposed action violates the intent of the Code to allow some latitude in forming names when strict adherence would cause confusion. Such latitude is mentioned in Rule 47a (22, p. 39):

When two or more taxa of the same rank from subtribe to family inclusive are united under a taxon of higher rank, the higher ranking taxon should derive its name from the name of the earliest legitimate genus that is a type genus of one of the lower ranking taxa.

If, however, the use of this generic name would lead to confusion in bacteriology, then the author may choose as type a genus which, in his opinion, leads to the least confusion and, if in doubt, should refer the matter to the Judicial Commission.

The wording "which in his opinion, leads to the least confusion" indicates that writers of the Bacteriological Code anticipated problems in the formation of names above the rank of genus and preferred solutions that would prevent confusion in the literature. This rule gives the author the prerogative of choosing a less confusing name instead of a confusing one just because it is based on an older type genus. This is still another example where an exception is specifically made part of a rule to minimize confusion in the literature.

The proposed action violates the intent of Rule $56 a$ (22, p. 43):

Only the Judicial Commission can place names on the list of rejected names (nomina rejicienda) (see Rule 23a, Note 4, and Appendix 4). A name may be placed on this list for various reasons, including the following.

(1) An ambiguous name (nomen ambiguum), i.e., a name which has been used with different meanings and thus has become a source of error. Example: Aerobacter Beijerinck 1900 (Opinion 46).

(2) A doubtful name (nomen dubium), i.e., a name whose application is uncertain. Example: Leuconostoc citrovorum (Opinion 45).

(3) A name causing confusion (nomen confusum), i.e., a name based upon a mixed culture. Example: Malleomyces Hallier 1870.

(4) A perplexing name (nomen perplexum), a name whose application is known but which causes uncertainty in bacteriology (see Rule 57c). Example: Bacillus limnophilus Bredemann and Stürck in Stürck 1935 (Greek-Greek, marsh loving) and Bacillus limophilus Migula 1900 (Latin-Greek, mud-loving); see Index Bergeyana, p. 196.

Nothing in the wording of the rule or the four examples even hints at a specific reason for rejecting Enterobacteriaceae. All of the abovementioned reasons have to do with a name which is causing a problem in nomenclature or in the scientific literature. Enterobacteriaceae Rahn 1937, nom. fam. cons. 1958, is not such a name.

The proposed action violates Rule $56 \mathrm{~b}(22, \mathrm{p}$. 44):

A conserved name (nomen conservandum) is a name which must be used instead of all earlier synonyms and homonyms.

Note 1. A conserved name (nomen conservandum) is conserved against all other names for the taxon, whether these are cited in the corresponding list of rejected names or not, so long as the taxon concerned is not united with another taxon bearing a legitimate name. In the event of union or reunion with another taxon, the earlier of the two competing names is adopted in accordance with Rules $23 a, b$.

Note 2. Only the Judicial Commission can place names on the list of conserved names (nomina conservanda) (see also Rule 23a, Note 4 and Appendix 4).

In the present controversy the name Enterobacteriaceae Rahn 1937, nom. fam. cons. 1958, has not "been united with another taxon bearing a legitimate name"; thus, the proposed action clearly violates this rule. Similarly, if this power had been intended, Note 2 would have been 
worded: "Only the Judicial Commission can place names on, or remove names from, the list of conserved names...." Rule 56b alone causes serious questions about the legality of the proposed action, since it clearly violates this rule.

The proposed action goes against the intent of Rules $57 \mathrm{c}$ and 58 (22, p. 45).

\section{Rule $57 \mathrm{c}$}

When two or more generic names, or two or more epithets in the same genus are so similar (although the words are from different sources) as to cause uncertainty, they may be treated as perplexing names (nomina perplexa) and the matter referred to the Judicial Commission (see Rule 56a[4])... .

Rule 58

When there is doubt about different spellings of the same name or epithet, or where two spellings are sufficiently alike to be confused, the question should be referred to the Judicial Commission which may issue an Opinion as seems fit. If one of the spellings is preferred by the Judicial Commission, this spelling should be used by succeeding authors.

Both of these rules indicate that it is unwise to have two names with similar spellings if they are names of different taxa. Enterobacteraceae is almost identical to Enterobacteriaceae, but they are based on different type genera and are thus different taxa. This is quite different from the orthographic variants Lapage mentioned (Haemophilus and Hemophilus), which were based on the same type and are the same taxon (22, p. 46). Enterobacteraceae Lapage 1979 based on Enterobacter Hormaeche and Edwards 1960 , nom. gen. cons. 1963, could also be confused with Enterobacteriaceae Rahn 1937 since they are both based on Enterobacter.

The proposed action goes against the intent of Article 9 (22, p. 144-146), which defines the duties and responsibilities of the taxonomic subcommittees. Section (d) says that one of the functions of a Subcommittee is "to make recommendations in relation to the nomenclature of the organisms in the taxon under study. This would include recommendations for changes in names and the conservation and rejection of names." A later section (8, p. 146) admittedly gives the Judicial Committee the final decision. But the question arises as to why the taxonomic subcommittees are even consulted on nomenclatural questions if the Judicial Commission can overrule an almost unanimous vote.

Discussion. The issues in this controversy seem to be clear. Is it more important to have no exceptions to one of the rules of the Bacteriological Code (18), or is it more important to maintain the name Enterobacteriaceae, which has been widely used in the literature for over
40 years (12)? The Judicial Commission has issued a "policy" that there can be no exceptions to the rules on the formation of names of taxa (18). We strongly disagree with the formation of this inflexible policy, since it is specifically contradicted by Principle 8 of the 1975 Code which allows for exceptions. It is also contradicted by decisions of previous Judicial Commissions which have often allowed exceptions to the rules in the interest of minimizing confusion in nomenclature. To implement legally the "policy of no exceptions," the Bacteriological Code would require modification, and we would strongly oppose such an attempt. "Bench" microbiologists complain that specialists in bacterial systematics more often produce instability in nomenclature rather than stability. The attempt to change the name Enterobacteriaceae is the strongest argument thus far available to support this contention.

The decision to reject the name Enterobacteriaceae with its type genus Escherichia has not received the support of those who work with the family. The Enterobacteriaceae Subcommittee voted 12 to 2 against this action. Similarly, the ASM Subcommittee on Gram-Negative Facultatively Anaerobic Rods voted 7 to 0 against the proposal. This overwhelming opposition to the proposals suggests that the name Enterobacteriaceae may well continue to be used by most microbiologists whether it is legitimate or illegitimate.

We believe that the current controversy has raised serious doubts as to whether the Judicial Commission can act as both a legislative and a judicial body on the same disputed nomenclatural question. The manner in which the Judicial Commission referred the matter to the Enterobacteriaceae Subcommittee indicated that it was not seeking advice but was asking the Subcommittee to endorse one of the two actions the Commission had already decided were the only possibilities. The Enterobacteriaceae Subcommittee voted for a third alternative which it believed would be the best course for maintaining stability in nomenclature. The Judicial Commission then changed from a legislative to a judicial body and voted to overturn the vote of the Enterobacteriaceae Subcommittee (18) and that of a previous Judicial Commission, made final by the International Committee on Systematic Bacteriology. In essence, it was voting for an option it had itself proposed. The following facts cast grave doubts about whether the Judicial Commission can objectively judge an issue when the Commission itself has already taken an advocate's role. The Commission voted (18, Minute 29) on the dispute 8 months before 
an opinion was even requested (21). This did not follow the procedure given in the Bacteriological Code. The Code requires that a request be made; this is then followed by a period of discussion and objections to the request (if any). Only then, after all the evidence has been submitted, is the Judicial Commission to consider the matter. Traditionally, a period of 3 to 5 years has been necessary from the time of the request for an opinion to a formal vote. In its haste to affirm its own proposal (18), the Judicial Commission voted (18) to conserve the name Enterobacter. aceae, which had never been published, had no description, was illegitimate, and had no standing in nomenclature. The Commission voted to conserve this illegitimate name (18) instead of Enterobacteriaceae Rahn 1937, nom. fam. cons. 1958, which has been used in the literature perhaps 100,000 times, was a conserved family name (19), was legitimate (5), was preferred by the Enterobacteriaceae Subcommittee, and was the only correct name for the family under the Bacteriological Code.

It is inconceivable that the name Enterobacteriaceae Rahn 1937, nom. fam. cons. 1958, was also omitted from the Approved Lists of Bacterial Names. This action has no basis in the Bacteriological Code. The appearance on the Approved Lists of the conserved name Enterobacteriaceae Rahn 1937, nom. fam. cons. 1958, is specifically demanded by Rule $56 \mathrm{~b}$, Note 1 . The explanation given $(27$, p. 236) for omitting Enterobacteriaceae Rhan 1937, nom. fam. cons. 1958 , was that the matter was sub judice. However, names were not uniformly omitted if they were sub judice. Holmes and Owen (14) challenged the name Flavobacterium aquatile as a doubtful name (nomen dubium) and requested that Flavobacterium breve be substituted for it as the type species for the genus Flavobacterium. With this challenge, the name $F$. aquatile became sub judice both as a valid species and as the type species for the genus Flavobacterium. However, the sub judice name Flavobacterium aquatile appeated on the Approved Lists of Bacterial Names compiled by Skerman, McGowan, and Sneath, but the sub judice name Enterobacteriaceae Rahn, nom. fam. cons. 1958, did not. No explanation of this inconsistency was given. In the proposed rejection of Enterobacteriaceae, the Judicial Commission's role has clearly been that of advocate, not as an impartial judge. We believe the Bacteriological Code should be modified to separate these two conflicting roles, since it makes no sense to have a judicial body rule on an issue it has proposed itself.

Since 1 January 1980, there has been no validly published name for the family Enterobac- teriaceae (27). Several names could be proposed. The name Enterobacteraceae is totally unacceptable for the many reasons that we have discussed previously. Only 2 of 12 members of the Enterobacteriaceae Subcommittee favored this name. A new family name Escherichiaceae could be coined and proposed. Purely from the standpoint of conformity to Rule 9 (22, p. 13), this is the only pessible choice, since it would be based on Escherichia, the only type genus which is acceptable for the family. The name Escherichiaceae should not be proposed because it would cause much unnecessary confusion in the literature and would probably be rejected by the scientific community. None of the 14 members of the Enterobacteriaceae Subcommittee voted for this name. Similarly, the Judicial Commission did not favor this name (18). Fortunately, a new name for the family based on one of its other genera has never been considered for obvious reasons. Thus, by elimination, there is only one possibility which would maintain stability in nomenclature and avoid confusion in the literature. In a separate paper (11) in this issue of the IJSB, we propose the name Enterobacteriaceae based on the type genus Escherichia.

Originally, this matter was definitively settled in 1958 with the conservation of Enterobacteriaceae in Opinion 15 (19). We totally oppose the efforts to revoke this definitive decision. With the publication of Enterobacteriaceae fam. nov., nom. rev., the issue is settled again. Lapage's Request for an Opinion has lost its judicial basis since Enterobacteraceae Lapage 1979 lost standing as \& validly published name on $1 \mathrm{Jan}$ uary 1980. Enterobacteriaceae has achieved worldwide acceptance over the last 40 years, it became a conserved family name in 1958 by Opinion 15 (19), it is legitimate (5), and since 1958 it has been the only correct name of the family under the Bacteriological Code. The use of any other name would violate the intent of having an internationally standardized system of nomenclature and would probably not be used in the literature. The ultimate test of any name is whether it is accepted and used. No one can doubt that the name Enterobacteriaceae has passed that simple test.

\section{ADDENDUM IN PROOF}

In July 1980, after receiving all the current arguments concerning the controversy (including copies of reference 12 and preprints of this manuscript and reference 11), the ICSB Subcommittee on the Taxonomy of Enterobacteriaceae reconsidered the question of the family name and type genus. The Subcommittee voted 11 to 0 both to retain the name Enterobacteriaceae and retain the type genus as Escherichia. (D. J. B.) 


\section{REPRINT REQUESTS}

Address reprint requests to: Center for Disease Control, Attn. J. J. Farmer III, Building 1, Room B341, Atlanta, GA 30333.

\section{LITERATURE CITED}

1. Bergey, D. H., R. S. Breed, E. G. D. Murray, and A. P. Hitchens. 1939. Bergey's manual of determinative bacteriology, 5th ed. The Williams \& Wilkins Co., Baltimore.

2. Brenner, D. S., and S. Falkow. 1971. Molecular relationships among members of the Enterobacteriaceae. Adv. Genet. 16:81-116.

3. Buchanan, R. E. 1957. How bacteria are named and identified, p. 15-28 In R. S. Breed, E. G. D. Murray, and N. R. Smith (ed.), Bergey's manual of determinative bacteriology, 7th ed. The Williams \& Wilkins Co., Baltimore.

4. Buchanan, R. E., and N. E. Gibbons. 1974. Bergey's manual of determinative bacteriology, 8 th ed. The Williams \& Wilkins Co., Baltimore.

5. Buchanan, R. E., J. G. Holt, and E. F. Lessel, Jr. 1966 Index Bergeyana. E\&S Livingstone Ltd., London.

6. Buchanan, R. E., R. St. John-Brooks, and R. S. Breed. 1948. International bacteriological code of nomenclature. J. Bacteriol. 55:287-306.

7. Drafting Committee, Judicial Commission. 1978. Proposal to emend the International Code of Nomenclature of Bacteria. Int. J. Syst. Bacteriol. 28:337.

8. Editorial Board, Judicial Commission. 1951. The formation of the names of taxonomic groups (taxa) of higher rank than genus. Int. Bull. Bacteriol. Nomencl. Taxon. 1:58-63. (The pages in issue no. 2 of volume 1 were renumbered; in the original issue, the pages are numbered 10-15.)

9. Editorial Board, Judicial Commission. 1951. Status of the generic name Bacterium, the specific name Bacterium coli, and the family name Bacteriaceae. Preliminary statement, file no. 5. Int. Bull. Bacteriol. Nomencl. Taxon. 1:64-79.

10. Editorial Board, Judicial Commission. 1957. Proposal to conserve the family name Enterobacteriaceae and to designate the type genus. Int. Bull. Bacteriol. Nomencl. Taxon. 7:165-166.

11. Ewing, W. H., J. J. Farmer III, and D. J. Brenner. Proposal of Enterobacteriaceae fam. nov., nom. rev. to replace Enterobacteriaceae Rahn 1937, nom. fam. cons. (Opinion 15, Jud. Comm. 1958), which lost standing in nomenclature on 1 January 1980 . Int. J. Syst. Bacteriol. 30:674-675

12. Farmer, J. J., III, D. J. Brenner, and W. H. Ewing. 1980. Enterobacteriaceae: judicial action has been proposed which would make it a rejected name and prevent its use in the literature. ASM News 46:275-279.

13. Haupt, H. 1957. Enterobacteriaceae Rahn 1937, an illegitimate name. Int. Bull. Bacteriol. Nomencl. Taxon. 7: 127-128.

14. Holmes, B., and R. J. Owen. 1979. Proposal that Flavobacterium breve be substituted as the type species of the genus in place of Flavobacterium aquatile and emended description of the genus Flavobacterium: sta- tus of the named species of Flavobacterium. Request for an opinion. Int. J. Syst. Bacteriol. 29:416-426.

15. International Code of Nomenclature of Bacteria and Viruses. 1958. Iowa State College Press, Ames.

16. International Committee on Bacteriological Nomenclature. 1953. Minutes of the meeting of the International Committee on Bacteriological Nomenclature held at Rome in connection with the VI International Congress for Microbiology, September, 1953. Meeting of the 7th September. Int. Bull. Bacteriol. Nomencl. and Taxon. 3:159.

17. International Committee on Systematic Bacteriology, XII International Congress for Microbiology. 1979. Minutes of the meetings, 5 and 7 September 1978, Munich, Germany. Int. J. Syst. Bacteriol. 29:168-169.

18. International Committee on Systematic Bacteriology, Judicial Commission. 1979. Minutes of the meeting, 3 September 1978. Int. J. Syst. Bacteriol. 29: 267-269.

19. Judicial Commission of the International Committee on Bacteriological Nomenclature. 1958. Conserva tion of the family name Enterobacteriaceae, of the name of the type genus and designation of the type species. Int. Bull. Bacteriol. Nomencl. Taxon. 8:73-74.

20. Judicial Commission of the International Committee on Systematic Bacteriology. 1973. Minutes of meeting, 29 August 1973, Jerusalem, Israel. Int. J. Syst. Bacteriol. 24:379-380.

21. Lapage, S. P. 1979. Proposal of Enterobacteraceae nom. nov. as a substitute for the illegitimate but conserved name Enterobacteriaceae Rahn 1937. Request for an opinion. Int. J. Syst. Bacteriol. 29:265-266.

22. Lapage, S. P., P. H. A. Sneath, E. F. Lessel, V. B. D. Skerman, H. P. R. Seeliger, and W. A. Clark (ed). 1975. International code of nomenclature of bacteria. American Society for Microbiology, Washington, D.C.

23. Middleton, R. B. 1972. The genetic homology of Salmonella typhimurium and Escherichia coli. Genetics 69: 303-315.

24. Middleton, R. B., and T. Mojica. 1971. Homology in Enterobacteriaceae based on intercrosses between species. Adv. Genet. 16:53-79.

25. Rahn, O. 1937. New principles for the classification of bacteria. Zentrabl. Bakteriol. Parasitenkd. Infektionskr. Hyg. Abt. 2 96:273-286

26. Sanderson, K. E. 1971. Genetic homology in the Enter obacteriaceae. Adv. Genet. 16:35-51.

27. Skerman, V. D. B., V. McGowan, and P. H. A. Sneath. 1980. Approved lists of bacterial names. Int. J. Syst. Bacteriol. 30:225-420.

28. Sneath, P. H. A. 1956. Conservation of the generic name Chromobacterium and designation of type strain. Int. Buli. Bacteriol. Nomencl. Taxon. 6:65-91.

29. Thurner, K., and M. Busse. 1978. Numerisch Taxonommisge Untersuchungen an Enterobakterien Aus. Oberflächenwasser. Zentralbl. Bakteriol. Parasitenkd. Infektionskr. Hyg. Abt. 1 Orig. Reihe A 167:262-271.

30. Wayne, L. G. 1975. Proposal to reject the specific epithet marianum in the name Mycobacterium marianum Penso 1953 and to conserve the specific epithet scrofulaceum in the name Mycobacterium scrofulaceum Prissier and Masson 1956. Request for an opinion. Int. J. Syst. Bacteriol. 25:230-231. 